University of Nebraska - Lincoln

DigitalCommons@University of Nebraska - Lincoln

3-1975

\title{
RECENT RESEARCH ADVANCES ON THE EUROPEAN CORN BORER IN NORTH AMERICA 1,2,3
}

\author{
T. A. Brindley
}

A. N. Sparks

W.B. Showers

W. D. Guthrie

Follow this and additional works at: https://digitalcommons.unl.edu/usdaarsfacpub

This Article is brought to you for free and open access by the U.S. Department of Agriculture: Agricultural Research Service, Lincoln, Nebraska at DigitalCommons@University of Nebraska - Lincoln. It has been accepted for inclusion in Publications from USDA-ARS / UNL Faculty by an authorized administrator of DigitalCommons@University of Nebraska - Lincoln. 


\section{RECENT RESEARCH ADVANCES ON THE EUROPEAN CORN BORER IN NORTH AMERICA ${ }^{1,2,3}$}

\section{T. A. Brindley}

Department of Zoology and Entomology, Iowa State University, Ames, Iowa 50010

\section{A. N. Sparks}

Agricultural Research Service, U.S. Department of Agriculture, Tifton, Georgia 31794

\section{W. B. Showers}

Agricultural Research

\section{W. D. Guthrie}

Agricultural Research Service, U.S. Department of Agriculture, Ankeny, Iowa 50021

\section{BIOLOGY AND ECOLOGY}

\section{Distribution}

The recorded distribution of the European corn borer, Ostrinia nubilalis, has not changed significantly since Brindley \& Dicke's review in 1963 (15), except along the southernmost portion of its range. Annual articles presenting the status of the European corn borer (3) indicate that each year the borer spreads into a few previously uninfested counties within known infested states. Sparks \& Young (116) made a survey and found 34 of 35 counties infested in southern Georgia and

${ }^{1}$ The survey of the literature pertaining to this review was concluded in March 1974.

${ }^{2}$ Paper No. J-7841 of the Iowa Agriculture and Home Economics Experiment Station, Ames, Iowa. Project No. 1923. In cooperation with the University of Georgia College of Agriculture Experiment Stations, Coastal Plain Station, Tifton, Georgia.

${ }^{3}$ Mention of a pesticide or proprietary product in this paper does not constitute a recommendation or an endorsement of this product by the USDA or cooperating agencies. 
concluded that the borer probably was present in all areas of extensive corn production in Georgia. Light-trap records from Tifton, Georgia, indicate that the borer's seasonal life history is very similar to its life history in South Carolina (31) and in Alabama (32). There are three complete generations each year and a fourth generation completes development in most years. Although official records do not show the presence of the borer in Florida, records from the southern tier of counties in Alabama (H. F. McQueen, personal communication) and in Georgia (116) indicate that corn-growing areas of the Florida panhandle probably are infested. Showers, Reed \& Brindley (109) conducted laboratory studies and concluded that the Georgia borer had adapted to the photoperiod-temperature interaction of the region and was capable of producing large numbers of moths for the summer and autumn generations.

Chiang (20) studied the dispersion of the borer in Minnesota and in South Dakota from 1945 to 1970 and suggested that after the initial invasion in 1943, two distinctly different populations could have invaded Minnesota, one in 1952 and one in 1966. Chiang \& Hodson (21) concluded that populations in the Waseca, Minnesota, area were kept at relatively low levels by environmental factors, but that with favorable temperatures, the borer populations could return to an economically significant level.

A highly successful cooperative project involving several North Central states has added significantly to available knowledge of the general biology and ecology of the European corn borer $(24,35,58,59,121)$. Other studies show that the borer can be separated into several biotypes on the basis of differential responses to diapause, survival, and feeding habits when collections from several areas are subjected to common conditions in the field $(22,107,120)$ or in the laboratory $(107,117)$. Morphometric differences involving five characters were used to separate borers from four locations into biotypes in 1967 (73), and then ten morphometric characters of female adults were utilized to further distinguish the biotypes in 1970 (23).

\section{Diapause}

The diapause characteristic of the borer has been studied by several researchers. Laboratory studies have shown significant differences in the abilities of diapausing vs nondiapausing larvae to synthesize and incorporate DNA and RNA precusortype macromolecules (56). Lynch, Brindley \& Lewis (85) studied the factors that influence survival of laboratory-reared larvae at subzero temperatures. They measured survival and oxygen consumption and detected no differences in diapause intensity due to exposure of larvae to decreasing photophases or lower temperature during the induction of diapause. After diapause was induced, conditioning to low temperatures and the length of the conditioning were associated with increased survival.

Beck and co-workers (5-8) have conducted numerous laboratory studies concerning the physiology of diapause in the European corn borer. They discovered, named, and further researched a developmental hormone, proctodone, that plays a role in diapause development and prepupal morphogenesis. Proctodone is secreted by the ileal epithelium of the anterior intestine, is photoperiodically sensitive on a rhythmic 
basis, and is believed to be associated with one of the basic elements of the insect's photoperiodic system.

Sparks, Brindley \& Penny (117) and Sparks et al (120) conducted studies with geographical populations of the borer. Egg masses from parental stocks collected in Minnesota, Iowa, and Missouri were used to inf est caged corn in Waseca, Minnesota; Ankeny, Iowa; and Portageville, Missouri. The $F_{1}$ progeny of these parental stocks exhibited significant differences in survival and diapause characteristics (120). Laboratory and field studies utilized three parental stocks to produce nine $F_{1}$ generations for study of the effects of temperature and photoperiod on diapause. These experiments provided evidence that diapause in the borer is controlled by a multigenetic makeup that responds to temperature and photoperiod (117). Further studies with similar techniques by Chiang, Keaster \& Reed (22) revealed that the Missouri borer population was more responsive to photoperiod and temperature than was the Minnesota population. Showers, Brindley \& Reed (107) conducted field studies at Ankeny, Iowa and Morris, Minnesota in which parental stocks from Minnesota, Alabama, and Maryland were used to produce nine $\mathrm{F}_{\mathbf{1}}$ generations. Again, significant differences in survival and diapause characteristics were shown among the biotypes of the three locations. The degree of expression of these differences is governed by the environment, primarily photoperiod and temperature. $\mathbf{W}$. B. Showers et al (unpublished observations) showed that the effect of the interaction of photoperiod and temperature on the diapause response places the corn borer populations of North America into three ecotypes: northern (univoltine), central (multivoltine), and southern (multivoltine).

\section{Development}

A study of the relationship between the borer and constant and variable temperatures resulted in the advancement of theoretical development thresholds of 12.2, 11.1 , and $12.8^{\circ} \mathrm{C}$ for the egg, larval, and pupal stages, respectively (86). Matteson \& Decker (86) also found that controlled variable temperatures within the normal range of development had little effect on the durations of the immature stages. In a field study conducted by Blantran de Rozari (10), however, the minimum temperature and fluctuations of temperature usually were the determining factors in the rate of development; these two temperature parameters were responsible for $37-53 \%$ of the variation. Jarvis \& Brindley (69) summarized 12 years of data from Boone County, Iowa, in which the relationship between temperature accumulations and seasonal development of the borer were correlated. They developed a regression equation that allowed them to predict the date of any desired percentage hatch of first- and second-generation oviposition or moth flight for the Boone County area. Hill \& Keith (57) found that above average second-generation populations (225 borers/100 plants) in Nebraska, could be predicted by July 15 of each year on the basis of 1500 or more accumulated degree days. That temperature has a tremendous effect on the borer in nature was documented (106) in the report of a partial third generation produced in 10 of 17 years (1950-1966) in Boone County, Iowa. The partial third generation, however, succumbed to the below-f reezing temperatures of autumn. But, the accumulation of 690.5 borer degree days between August 22 and 
October 8, 1970, resulted in the development and survival of a third generation and allowed Showers \& Reed (106) to speculate that $68 \%$ of the Boone County borer population entering the winter of 1970-1971 were third-generation insects.

\section{Mating}

The interaction of temperature and mating was first recorded in the laboratory when Sparks (112)' observed that copulation was achieved when adults were exposed to a falling temperature in phase with a light-dark $14: 10-\mathrm{hr}$ photoperiod. Loughner and Brindley (82-84) made more thorough studies of the effects of photoperiod, thermoperiod, and other environmental factors on mating behavior and success of the borer. Decreasing temperatures $\left(29.4-19.4^{\circ} \mathrm{C}\right)$, decreasing light intensities $(250-0.1$ $\mathrm{ft}-\mathrm{c})$, and intermediate to high relative humidities served as exogenous synchronizers for mating. Full moonlight (90) and wind speeds in excess of $15 \mathrm{~km} / \mathrm{hr}$ were inhibitory. Showers, Reed \& Oloumi-Sadeghi (110) discovered that temperature plateaus of at least $2 \mathrm{hr}$ duration per night were essential for activation of the mating response. The plateaus were less of a requisite for the searching behavior of the male than for the pheromone activity of the female.

\section{Pheromones}

A chemical stimulus emitted by the female European corn borer was documented by Sparks (113), isolated and confirmed by Klun (74), and identified as Z-11tetradecenyl acetate (Z-11-tda) by Klun \& Brindley (75). Klun \& Robinson (76) reported that the opposite geomterical isomer, $E$-11-tetradecenyl acetate $(E-11$ tda), inhibited attraction of the male European corn borer indigenous to central Iowa. But, Roelofs et al (99) reported that the European corn borer in New York was attracted specifically to the geometrical isomer $E$-11-tda. Later, Klun \& Robinson (77) showed elicitation of a sex-attraction response by a combination of geometrical isomers, some of which attracted as many male European corn borers as did relatively pure Z-11-tda. Males of other species of Lepidoptera also were attracted to some of the test chemicals. They hypothesized that specific concentrations or blends of ehemicals might be important in keeping certain lepidopteran species apart.

In New York, Roelofs et al (99) found that 14-day old Z-11-tda was as effective as fresh $E$-11-tda in attracting male European corn borers. Oloumi-Sadeghi (90) reported that the attractancy of a combination of $91.5 \% Z$ and $8.5 \% E$-11-tda decreased as the lure became three nights old. The attractancy of pure $Z$-11-tda increased significantly, however, as it became three nights old. He hypothesized that a change in concentration or isomeric configuration $(Z$ to $E)$ was taking place. Later Klun et al (78) reported that minor amounts of $E$ isomer in the $Z$ were necessary for maximum sex attraction by the Iowa strain of European corn borer.

Showers, Reed \& Oloumi-Sadeghi.(110) found that the male European corn borer in Iowa is attracted to female corn borers of Georgia, Minnesota, and Quebec, as well as females of Iowa, but shows little response to female European corn borers from New York. From diapause response, the female populations from Minnesota and Quebec used in the test by Showers, Reed \& Oloumi-Sadeghi (110) represent the northern ecotype (univoltine); those from Iowa, the central ecotype; and those from Georgia, the southern ecotype. Therefore, on the North American continent, 
the two known pheromone races (predominantly $Z$ vs predominantly $E$ ) do not coincide with, but transcend the diapause races of the European corn borer.

Studies of the European corn borer antennae were undertaken by Cornford, Rowley \& Klun (26). They tentatively assigned the roll of pheromone receptor to Type-A sensilla trichodea because the sexual dimorphism favored the male, and secondly because this sensillar type resembled the sex pheromone receptor of Bombyx mori.

A great deal of research has been done on olfactory response of the European corn borer to pheromones. But, little is known of their capabilities to perform as a control mechanism. Oloumi-Sadeghi (90) discovered, through a comparison with light traps and pheromone traps, that males respond to synthetic sex attractant only after feral females have mated and initiated egg deposition. He also found that pheromonebaited traps captured a greater proportion of males sooner when adult populations were small. His results suggest that intensive trapping during the spring fight or a small summer flight might reduce subsequent larval populations.

\section{Radiation Sterilization and Juvenile Hormones}

Guthrie, Dollinger \& Stetson (45) developed techniques and studied spermatogenesis in the borer; they found a haploid chromosome count of 31 . They suggested that male sterilization could be obtained by irradiating: (a) third- and early fourth-instar larvae to affect only spermatogonia; $(b)$ late fourth-instar larvae to affect spermatogonia and early spermatocytes; (c) half- to full-grown fifth-instar larvae and early pupae to affect spermatocytes, spermatids, and mature spermatozoa; and $(d)$ adults to affect spermatozoa. Chaudhury \& Raun (19) completed additional studies of spermatogenesis and testicular development of the borer under a specific temperature regimen. They quantitatively determined the percentages of the testicular components in six developmental stages of germ cells, including spermatogonia, primary spermatocytes, secondary spermatocytes, spermatids, elongating sperm, and mature sperm. They concluded that testicular development increased rapidly during the larval and early pupal stages and that the adult insect contains its full complement of sperm.

Raun et al (97) discovered that severe somatic damage of nondiapausing larvae ensued after irradiation with gamma rays from a cobalt ${ }^{60}$ source, but diapausing larvae were unaffected. Irradiation of diapausing corn borers did not induce gene mutations but affected motility or viability of the sperm. Laboratory studies by Harding (51) and Jackson \& Brindley (68) showed that feeding or applying chemosterilants to corn borers sterilized the adults and that just $4 \%$ of the eggs deposited were viable. Lewis, Lynch \& Berry (81) studied the effect of synthetic juvenile hormones on the corn borer and noted that the compounds exerted a high degree of activity on treated larvae in the laboratory. However, there was no larval response to the JH-like compounds in the field, and the phytotoxicity to corn plants was slight to extreme with granular and liquid formulations, respectively.

\section{Light Traps}

Barrett, Day \& Hartsock (4) found that when adult European corn borer populations were low, one to five blacklight traps adjacent to sweet corn plots protected 
the crop from borer damage. There were, however, no significant differences in damaged plants between lighted and unlighted plots when corn borer populations were high (18-51\% infestation).

\section{Sound}

Pulse rate and amplitude of sound have been used to simulate those emitted by echolocating bats. Belton \& Kempster (9) obtained variable results with these devices when they tried to use them to control the corn borer. They attributed the variation to a possible change in moth behavior on wet vs dry nights and suggested that corn plants may act as a sound barrier. Thus, low-flying moths would not be exposed to high levels of sound. Agee (2) studied the tympanic organ of the corn borer and found it to be served by two acoustical cells and by one nonacoustical cell. The organ detected frequencies of 14 and $100 \mathrm{kHz}$ at 90 and $75 \mathrm{db}$, respectively. More moths showed avoidance response at pulse frequencies of $25 \mathrm{kHz}(80-90 \mathrm{db}$ at $1 \mathrm{~m}$ ). However, Belton \& Kempster (9) more than halved the infestation of European corn borer in sweet corn by blanketing the area with a frequency of 50 $\mathrm{kHz}$.

\section{Techniques}

Several spin-off projects have resulted in publication of technique papers of possible value to other entomological researchers. Sisson, Brindley \& Bancroft (111) reported on a statistical method for combining biological data from European corn borer experiments over years. Sparks \& Facto (115) described techniques for use of time-lapse infrared cinematography to study flight, mating, and feeding habits of the borer. Showers, Lewis \& Reed (108) reported on a method of identifying released insects that had been reared on wheat germ. Sparks (114) developed a microchamber for replicating photophases in diapause studies. Drecktrah, Knight \& Brindley (30) studied the morphology of the internal anatomy of the fifth-instar larvae; Drecktrah \& Brindley (29) studied the morphology of the internal reproductive systems of the adults, and Jones (72) did a definitive study on the postembryonic development of the reproductive system of the European corn borer.

\section{CONTROL}

\section{Biological}

Biological control is defined by Dicke (27) as a balance between a species and biological stress factors that limits the potential population. Research on biological control usually falls into one of five categories, having to do with parasites, predators, pathogens, radiation and genetics, or host plant resistance. The first three categories will be discussed in this section. Radiation and genetics and host plant resistance are discussed elsewhere in this review.

PARASITES In hope of stemming the phenomenal increase of the European corn borer in North America, 24 exotic species of insect parasites were imported during the 1920s, 1930s, and 1940s (15). By 1962, however, just six of these parasite species 
remained, and a tachinid, Lydella thompsoni ( $=$ grisescens), was considered the most effective and widely established. However, Franklin \& Holdaway (36) discovered that the fly was primarily attracted to a specific corn variety (habitat) and, secondarily, to the European corn borer (food host). Sparks, Raun \& Carter (118) reported that the fall population of $L$. thompsoni closely followed the fluctuations of the first-generation European corn borer and that in Boone County, Iowa, between 1951-1961, there was a reservoir of $1-29 \%$ parasitism by $L$. thompsoni of the fall borer population available to attack the first-generation corn borer during each succeeding spring. During 1958-1964, L. thompsoni and Eriborus terebrons (= Horogenes punctorius), reported by Townes (125), became increasingly prevalent among corn borer populations in Nebraska, and during 1960-1963, these two parasites parasitized 1.6-23\% of second-generation corn borers in Ohio (59).

Beginning with the 1963 season, there was a decline in European corn borer and L. thompsoni populations throughout the Corn Belt $(59,125)$. According to Hill et al (58), in 1966 L. thompsoni disappeared from Iowa, Minnesota, and Nebraska. Although European corn borer populations in these states attained a level of prosperity during 1968-1971, L. thompsoni did not reappear. During a similar resurgence of corn borer populations in Ontario, however, Wressel (125) reported that $L$. thompsoni had reappeared and was maintaining itself at a low level.

Another widely established exotic parasite is the eulophid, Simpiesis viridula (15). Thousands of this parasite were released in Quebec from 1931 to 1934 and from 1945 to 1947 (63), but they were not recovered until 1964. Showers \& Reed (105) reported that, in Iowa, the female of $S$. viridula rarely searches the bottom portion of the corn plant, but $62-75 \%$ of the second-generation European corn borers tunnel into that part of the plant. They concluded that this characteristic behavior of the wasp is a factor that maintains $S$. viridula populations well below host population levels and, therefore, that the wasp would be of minor importance in controlling the European corn borer.

Wressel (125) conducted a census on $L$. thompsoni, $E$. terebrons, and S. viridula in southwestern Ontario from 1948 to 1964 and determined that these parasites are of minor importance in controlling European corn borers. Miller (88) observed the activities of three native parasites, an ichneumonid, Campoletis sp., and two tachinids, Archytas marmoratus and Lixophaga sp., on first-generation European corn borers in Georgia and concluded that parasitism was insignificant.

P. Burbutis and C. Davis (unpublished observations) placed corn borer egg masses parasitized by Trichogramma nubilalum on sweet corn in the field and in the greenhouse. They found that parasites released in the lower one third to halfway up the plant were more effective in finding and parasitizing available egg masses. They achieved $5 \%$ parasitism by $T$. nubilalum at a time of year when natural parasitism by this species had not been observed.

PREDATORS Dicke \& Jarvis (28) reported that predation by Orius insidiosus peaked during early larval development in first-generation European corn borers and was a significant factor in control. There was little predation by $\boldsymbol{O}$. insidiosus, however, on early-instar larvae of second-generation corn borers, partly because 
corn pollination occurred at the same time, and because pollen became the principal food for $\boldsymbol{O}$. insidiosus and the corn borers became incidental food.

In North Dakota, Frye (37) reported that coccinellids and chrysopids are in synchrony with the single-generation corn borer and that when he used a predation index developed by Chiang and Holdaway (Brindley \& Dicke, 15) he found that these predators reduced European corn borer populations by ca 83 and $72 \%$ during 1966 and 1967, respectively. Carlson \& Chiang (18) were able to increase the number of chrysopids and the so-called four-spotted fungus beetle, Glischrochilus quadrisignatus quadrisignatus, in experimental corn plots by spraying sucrose solution on the plants. Chrysopid buildup was negated, however, if aphid populations were high. Sparks et al (119) demonstrated that although insect predators play an important part in corn borer population fluctuations at some locations during some years, they cannot be depended upon year after year, or in any given years, to alter significantly the borer population at any specific location.

Several species of birds have been observed preying upon overwintering European corn borers. However, the downey woodpecker, Dendrocopos pubescens, was reported to be the most important in Arkansas (124) and North Dakota (38).

PATHOGENS Hudon (62) found two preparations of the bacterium, Bacillus thuringiensis, reasonably effective in controlling the European corn borer. He concluded, however, that the bacterium was nothing more than a promising control agent for the corn borer. Raun (93) also reported variable laboratory and field results with strains of the bacterium. Raun, Sutter \& Revelo (96) determined that, in the laboratory, the bacterium lost its pathogenicity after $72 \mathrm{hr}$ of ultraviolet irradiation and that mortality of treated corn borer larvae was delayed at temperatures below $32^{\circ} \mathrm{C}$. Some of these ecological effects on pathogenicity, however, were decreased by encapsulation of the microbial insecticide (95). McWhorter, Berry \& Lewis (87) concluded that the variability between the bacterial varieties Bacillus thuringiensis var. thuringiensis and Bacillus thuringiensis var. alesti might be attributed to differences in potency as well as to the environment. They suggested that standardization of bacterial preparations and better means of application were the major problems in obtaining consistent corn borer control. Sutter \& Raun (122) determined that the microbial agent did not function as a toxicant in the European corn borer but that $B$. thuringiensis var. thuringiensis caused the epithelial cells to slough off into the lumen. It thus exposed areas of the basement membrane to attack by vegetative rods. Death then occurred as the vegetative rods entered the hemocoel and produced a septicemia. Esterline \& Zimmack (34) looked at the possibility of using the bacteria Escherichia coli and Serratia marcescens as microbial agents and concluded from histological results that these bacteria would not be useful in the control of European corn borer.

VanDenburg \& Burbutis (123) found that the naturally occurring microsporidian, Nosema (=Perezia) pyraustae, infected $80-85 \%$ of the European corn borer population in Delaware during 1959 and 1960 . Hill et al (59) reported that the $N$. pyraustae infection of the corn borer population in Iowa combined with the abnormally cool temperatures in the late summer of 1964 were suspected of causing the greatest 
autumn to postharvest reduction in borer populations recorded in that state. Furthermore, the complete lack of $N$. pyraustae infection in the fall of 1967-1969 partly explained the higher corn borer populations in Cuming County, Nebraska (58). Showers, Brindley \& Reed (107) found that $N$. pyraustae infection was most severe within a Minnesota population of European corn borer; the effect on survival was less severe among progeny of Minnesota and Alabama crosses than among progeny of Minnesota and Maryland crosses. The potential use of $N$. pyraustae as a practical control of the European corn borer was considerably enhanced when L. C. Lewis and R. E. Lynch (unpublished observations) developed methods for lyophilizing, vacuum drying, and storing the protozoan in a form that can be formulated into granules or baits for field application.

Laboratory pathogenicity tests of the effects of fungi on corn borer larvae showed that Beauveria bassiana and Metarrhizium anisopliae produced 93 and $78 \%$ mortality, respectively (16). However, Aspergillus niger, until recently a chronic problem in laboratory rearing of the corn borer, produced only $1 \%$ mortality.

The search for viruses that might affect corn borer populations has been less successful. Raun (94) reported a virus-like disease, and electron microscopy of the diseased fat-body tissues revealed hexagonal particles thought by Adams \& Wilcox (1) to be icosahedra, but a pathogen was not isolated.

The survey of research concerning biological control agents for the corn borer (parasites, predators, and pathogens), therefore, points up that there are at least two potential agents that may control the insect, the bacterium, $B$. thuringiensis, and the protozoan, $N$. pyraustae. However, no biological agents are now consistently operative at a sufficient level to control the European corn borer in North America. This was also the conclusion of Chiang \& Hodson (21) when they found that there was no consistency or host-density dependence of natural enemies of the corn borer in Minnesota. Further, they concluded that since 1952 corn borer populations have been kept relatively low by climatic and agricultural changes.

\section{Chemical}

Interest in the use of chemicals for borer control in recent years has been greatest among the producers of specialty crops, such as hybrid seed, canning, and market garden corn, and peppers. Previously DDT was used extensively. Jackson (65) made 33 comparisons with granular formulations and 13 with spray formulations of other promising insecticides. He found that granular formulations of diazinon, carbaryl, and endrin gave satisfactory control, but that DDT was the most effective of the spray formulations. Harding, Lovely \& Dyar (53) concluded that carbaryl, diazinon, and carbofuran gave satisfactory control of the first-generation borer. Carbofuran, EPN [ $O$-ethyl $O$-( $p$-nitrophenyl) phenylphosphonothoate], and diazinon were equally as effective in controlling second-generation borers, but carbaryl was significantly less effective. Berry et al (13) found that granular formulations of diazinon, carbaryl, malathion, carbofuran, and EPN gave satisfactory control of the borer. However, persistence of an insecticide depends on the structure of the chemical, as well as on the formulation of the material. Harding et al (55) compared granular, capsular, and ultra-low volume formulations of diazinon. They reported that ultra- 
low volume residues were greatest on leaves and least in the whorl where residual toxicants are the most effective. Residues from the granular and capsular formulations were greatest in the whorl. Residues from all formulations were completely absent seven days after application.

Munson et al (89) reported that when insecticides were applied to corn foliage, 80 to $90 \%$ of the granules applied over the row fell to the ground and that the material on the ground then controlled larvae of the western corn rootworm, Diabrotica virgifera. Thus the European corn borer and the corn rootworms could be controlled with a single application of insecticide, and this, combined with the control of the two species of insects, would reduce the cost and amount of pesticides used on cropland. Hills, Peters \& Berry (60) compared the effectiveness of planting and postplanting treatments for the control of first-generation corn borers and western corn rootworms. Both treatment times were effective in controlling corn rootworms, but the most effective control of borers was achieved with postplanting applications.

Jackson $(66,67)$ obtained partial control of first-generation borers with American Cyanamid CL 47470 (cyclic propylene $P, P$-diethyl phosphonodithiomidocarbonate) and carbofuran. His work showed that these materials were more effective when applied as a band $6.3 \mathrm{~cm}$ to one side of the seed and at the same depth as the seed. Harding (50) reported that granular formulations of CL 47470, CL 47470 + phorate, carbofuran, propoxur, Ortho ${ }^{\oplus} 9006(O, S$-dimethyl phosphoramidothioate), and dioxacarb were effective in reducing the numbers of borer cavities. Edwards \& Berry (33) showed that carbofuran, TD-5032 (hexamethylditin), and CL 47470 applied at time of planting and at a rate of $4.0 \mathrm{lb}$ actual insecticide/acre were effective for borer control 50 days postapplication.

The biology of an insect determines the most effective placement of an insecticide for optimum control. For example, when foam was used by Berry (11) and by Berry, McWhorter \& Lovely (12) as an insecticide carrier, these formulations were as effective or, in some instances, more effective than the traditional sprays or granular formulations. Also, reduced rates were as effective as full rates.

Entomologists were also concerned with the possibility that the corn borer might develop resistance to insecticides. Harding \& Dyar (52) demonstrated that when borer larvae were exposed to DDT, diazinon, and carbaryl over 12 generations in the laboratory, selection resulted in strains with some resistance to the chemicals. They also found that there was no cross-over of tolerance.

Most recommendations for the control of the European corn borer with insecticides were developed for moderate plant populations arranged in 40-inch rows. In recent years, however, the use of narrow rows and high plant populations has become standard practice. Harding et al (54) determined the effect of these new practices on borer control with DDT. These workers found that neither the establishment nor the control of first- or second-generation borers was significantly affected by row spacing or plant populations. But control of both borer generations tended to decrease as plants were grown closer together.

Insecticide applications for corn borer control are not limited to corn. In some locations, this pest may damage such crops as peppers, potatoes, and snap beans. 
Moreover, seed or field corn can tolerate low borer populations without suffering substantial reduction in yield, but vegetable buyers demand high-quality vegetables free from insect damage and contamination. Burbutis et al (17) reported excellent control of the borer on pepper with 1.5 and $2.0 \mathrm{lb}$ DDT/acre; however, it was necessary to maintain a weekly spray schedule from early in July until the first week of September.

Insecticides that show systemic activity have also been used on peppers. Ryder, Burbutis \& Kelsey (101) reported that carbofuran and CL 47470 significantly reduced European corn borer infestations in peppers but did not give commercially acceptable control of the borer.

The effects of the corn borer in reducing potato yields are not clear cut; however, in some cases a reduction in yield occurred as a result of the borer feeding on the foliage. Bray (14) reported successful control of the European corn borer with applications of DDT, Kepone ${ }^{\circledast}$ [decachlorooctahydro-1-3-4-methene-2H-cyclobuta(cd) pentalen-2-one], phosphamidon, carbaryl, and endosulfan. Control of the borer population, however, did not result in increases in yield. Hofmaster, Waterfield \& Boyd (61) controlled corn borers with soil applications of carbofuran and fensulfothion, but the increases in yield reported by these researchers may have occurred as a result of controlling the Colorado potato beetle, Leptinotarsa decemlineata, and the potato tuberworm, Phthorimaea operculella, as well as the corn borer.

\section{Varietal Resistance}

PLANT BREEDING AND GENETICS Brindley \& Dicke (15) reviewed research on host-plant resistance through 1961. Guthrie (40) wrote a comprehensive review of techniques, accomplishments, and the potential of breeding for resistance to European corn borers in corn. Gallun, Starks \& Guthrie (39) reviewed the chemical basis of resistance to first-generation borers.

If insects such as the European corn borer have more than one generation each season, the biological relationship between the insect and host plant may not be the same for each generation. In the Corn Belt states, resistance to first-generation borers is actually leaf-feeding resistance, because young larvae of the first generation feed primarily on the spirally rolled leaves in the whorl (43). Resistance to a second-generation infestation is actually resistance to collar- and sheath-feeding (second-generation larvae infest plants when corn is shedding pollen and silks are emerging), because young larvae feed on pollen accumulation at the axils of the leaves and on sheath, collar, and husk tissue. Most of the feeding, however, is on sheath and collar tissue $(46,47)$. In host-plant resistance research, therefore, the word generation is meaningless; the growth stage of the plant being attacked is important. Researchers should be aware that plant material resistant to insects during the vegetative stage of development may not be resistant during pollen shedding and later stages. For example, inbred lines of corn that are resistant to leaf feeding (first generation) by the European corn borer may be highly susceptible to sheath and collar feeding (second generation). Inbred lines that are resistant to second-generation larvae may not be resistant to first-generation larvae, but some lines may have some resistance to both generations. 
Resistance to the first-generation borer has been easy to find (41), but resistance to the second generation has been more difficult to find in corn germ plasm. Although over 600 entries were evaluated for second-generation resistance, only inbred B52 has shown a high level of resistance $(48,92)$.

During the 1940s and 1950s many corn hybrids, all double crosses, were extremely susceptible to leaf feeding by a first-generation infestation. Today most corn hybrids have a lower level of susceptibility, and many have at least an intermediate degree of resistance (40). In recent years, most farmers have planted single crosses or simulated single crosses instearl of double-cross hybrids. In general, single crosses with the following combinations of inbred lines are effective in reducing populations of first-generation borers: Resistant $X$ Resistant, Intermediate $X$ Intermediate, Resistant X Intermediate, or Resistant X Susceptible. Either dominance or incomplete dominance of resistance is necessary if the Resistant $X$ Stisceptible combination is to be effective (15).

Hybrids used today differ in degree of tolerance (ability to stand up under a moderate-to-heavy infestion) to a second-generation infestation, but all are susceptible to sheath and collar feeding (W. D. Guthrie, unpublished observations). Breeding for resistance to both generations of the European corn borer is, therefore, of great interest to researchers. Work is underway to evaluate breeding methods for selecting for both first- and second-generation resistance in the same plant population (48).

In most instances, resistance to frst-generation European corn borers is conditioned by genes at several loci, and effects are cumulative among loci. Scott, Dicke \& Penny (102) used reciprocal translocations and reported that five chromosome arms in CI31A and six arms in B49 carried genes for first-generation resistance. Scott, Hallauer \& Dicke (104) determined the type of gene action involved in first-generation resistance by using $F_{2}, F_{3}$, and selfed backcross populations of $\mathrm{CI} 31 \mathrm{~A}(\mathrm{R}) \times \mathrm{B} 37(\mathrm{~S})$, plus individual $\mathrm{F}_{2}$ plants of $(\mathrm{CI} 31 \mathrm{~A} \times \mathrm{B} 37) \times \mathrm{CI} 31 \mathrm{~A}$, and individual $\mathrm{F}_{2}$ plants of $(\mathrm{CI} 31 \mathrm{~A} \times \mathrm{B} 37) \times \mathrm{B} 37$; most of the genetic variance for first-generation resistance was of the additive type.

Jennings et al (71) used a generation mean analysis to determine the genetic basis of second-generation resistance. The following nine populations were studied: $\mathbf{P}_{1}$, $P_{2}, F_{1}, F_{2}, F_{3}, B C_{1}, B C_{2}$, and selfed progenies of both backcrosses. In four different experiments, B52 was used as the resistant parent $\left(P_{1}\right)$, and B39, L289, Oh43, and WF9 were used as the susceptible parent $\left(\mathrm{P}_{2}\right)$. The data indicated no simple genetic basis of resistance and suggested that high resistance to a second-generation infestation may be the cumulative effect of an unknown number of loci. Additive genetic effects were predominant in conditioning resistance, but dominance was significant in all crosses. Scott, Guthrie \& Pesho (103) showed that this high resistance of B52 is also transmitted in hybrid combinations. Jennings, Russel \& Guthrie (70) used a diallel analysis involving 10 inbred lines and their 45 single crosses to demonstrate further that additive type of gene action conditions resistance to a second-generation infestation.

In early efforts to breed for resistance to first-generation borers, the backcross method was not successful in transferring resistance to susceptible inbred lines. The 
desired genotypes could not be identified in the segregating generations; when more than two backcrosses were used, the needed level of resistance was lost. The level of resistance could be increased, however, by intermating among resistant plants in progeny of the first or second backcross (100).

Penny, Scott \& Guthrie (91) showed that recurrent selection was very effective in increasing the level of resistance to first-generation corn borers in five corn populations. Recuirent selection is essentially a breeding method of concentrating genes for certain desirable characters for which selection is being practiced while maintaining a broad gene base for other characteristics in the population. This procedure allows for the accumulation of desirable genes at numerous loci.

Frequencies of genes that condition resistance in corn to second-generation borers are low in populations of corn in the Corn Belt states (71). Consequently, population improvement is needed to increase the gene frequencies. A recurrent-selection technique is being used for selecting for resistance to both first- and second-generation borers in a ten-line synthetic corn hybrid (48). Ca 500 plants are infested in the whorl stage of development, and resistant plants are self-pollinated. The $S_{1}$ progenies are evaluated in replicated trials for resistance to first- and second-generation borers, and the best $10 \%$ of the lines are recombined to obtain an improved population.

\section{REARING}

In European corn borer resistance investigations, all plots are artificially infested with egg masses produced in the laboratory. Progress would be nil without this technique of artificial infestation (47).

For many years, first-generation egg production was obtained from moths that were collected from large emergence cages that had been filled with infested cornstalks the previous fall (49). Until recently, however, a good source of moths has not been available for second-generation egg production. Moths were obtained primarily by net collecting in patches of grass or weeds near corn fields that had a first-generation infestation or from infested, caged, green, sweet cornstalks (44).

The use of wheat germ marked the advent of the modern era of practical artificial diets for rearing plant-feeding Lepidoptera (25). During the past several years, European corn borer larvae have been reared individually in 3-dram vials on a plug of meridic diet; although over $90 \%$ survival is obtained $(49,79)$, this procedure is too slow to produce the number of moths needed for egg production in biological research. Therefore, during 1965-1973, larvae were reared on a meridic diet in plastic dishes $(25.0 \mathrm{~cm}$ diam, $8.8 \mathrm{~cm}$ deep). However, several disease problems occurred with dish-reared insects. The pathogens of primary importance were bacteria, protozoa, and fungi. This problem was solved in 1969 and 1971 by the use of aureomycin in the diet to suppress bacteria, Fumidil B to suppress protozoa (Nosema pyraustae,) and four fungal inhibitors (methyl $p$-hydroxybenzoate, propionic acid, formaldehyde, sorbic acid) to suppress fungi $(48,80,98)$.

Data collected during an 8-yr period showed that European corn borers reared continuously on a meridic diet cannot be used for screening inbred lines of corn 
because leaf-feeding damage is too low to measure resistance (48). For example, one culture at the European Corn Borer Laboratory (Ankeny, Iowa) that has been reared for 108 generations on a meridic diet had lost its virulence to infest corn plants by the thirty-fourth generation (64). Subsequently, crosses between

ture and a native population and backcrosses to each parent showed that the loss in virulence was genetically controlled (additive gene action in the insect) (42; Guthrie, unpublished observations). Cultures reared for 1 to 14 generations on a meridic diet performed as well as a feral population on corn plants (Guthrie, unpublished observations). Therefore, virulence is now maintained in corn borer cultures by dissecting 6000 feral larvae from cornstalks each fall to initiate new cultures (48).

During 1970-1973, ca 1,000,000 egg masses were produced each season for first-generation infestations (ca 25 eggs per mass) and more than 300,000 egg masses were produced for second-generation infestations. This technique has greatly accelerated research on second-generation resistance and on the biology and ecology, biological control, chemical control, and sex pheromones of the European corn borer (48). Also, two commercial seed corn companies are now rearing corn borers on meridic diets to provide large numbers of egg masses for studies of resistance to both first- and second-generation borers (Guthrie, unpublished observations).

With cooperation between federal, state, and private researchers, we are confident that corn hybrids will be developed that are resistant to all generations of the European corn borer. The American farmer will be the beneficiary of this cooperative research effort.

\section{Literature Cited}

1. Adams, J. R., Wilcox, T. A. 1965. A viruslike disease condition in the European corn borer, Ostrinia nubilalis (Hübner). J. Invertebr. Pathol. 7: 265-66

2. Agee, H. R. 1969. Acoustic sensitivity of the European corn borer moth, Ostrinia nubilalis. Ann. Entomol. Soc. Am. 62:1364-67

3. Agricultural Research Service. 19681973. USDA Coop. Econ. Insect Rep.

4. Barrett, J. R., Day, H. O., Hartsock, J. G. 1971. Reduction in insect damage to cucumbers, tomatoes, and sweet corn through use of electric light traps. $J$. Econ. Entomol. 64:1241-49

5. Beck, S. D., Alexander, N. 1964. Hormonal activation of the insect brain. Science 143:478-79

6. Beck, S. D., Alexander, N. 1964. Proctodone, an insect developmental hormone. Biol. Bull. 126:185-98

7. Beck, S. D., Alexander, N. 1964. Chemically and photoperiodically induced diapause development in the European corn borer, Ostrinia nubilalis. Biol. Bull. 126:175-84

8. Beck, S. D., Shane, J. L., Colvin, I. B. 1965. Proctodone production in the European corn borer, Ostrinia nubilalis. J. Insect Physiol. 11:297-303

9. Belton, P., Kempster, R. H. 1962. A field test on the use of sound to repel the European corn borer. Entomol. Exp. Appl. 5:281-88

10. Blantran de Rozari, M. 1973. Effect of temperature on the survival and development of the European corn borer, Ostrinia nubilalis (Hubn). MS thesis. Iowa State Univ., Ames. 58 pp.

11. Berry, E. C. 1972. Alternate methods for the control of European corn borers. Ill. Custom Spray Operators' Training Sch. Rep. 24:29-32

12. Berry E. C., McWhorter, G. M., Lovely, W. G. 1972. Foam as a carrier for insecticides and in corn insect control. Proc. N. Cent. Br. Entomol. Soc. Am. 27:147

13. Berry, E. C. et al 1972. Further field tests of chemicals for control of the European corn borer. J. Econ. Entomol. 65:1113-16 
14. Bray, D. F. 1961. European corn borer control in potatoes. J. Econ. Entomol. 54:782-84

15. Brindley, T. A., Dicke, F. F. 1963. Significant developments in European corn borer research. Ann. Rev. Entomol. 8:155-76

16. Brooks, L. D., Raun, E. S. 1965. Entomogenous fungi from corn insects in Iowa. J. Invertebr. Pathol. 7:79-81

17. Burbutis, P., Fieldhouse, D. J., Crossan, D. F., VanDenburg, R. S., Ditman, L. P. 1962. European corn borer, green peach aphid, and cabbage looper control on peppers. J. Econ. Entomol. 55:285-88

18. Carlson, R. E. Chiang, H. C. 1973. Reduction of an Ostrinia nubilalis population by predatory insects attracted by sucrose sprays. Entomophaga 18: 205-11

19. Chaudhury, M. F. B., Raun E. S. 1966. Spermatogenesis and testicular development of the European corn borer, Ostrinia nubilalis. Ann. Entomol. Soc. Am. 59:1157-59

20. Chiang, H. C. 1972. Dispersion of the European corn borer in Minnesota and South Dakota, 1945 to 1970. Environ. Entomol. 2:157-61

21. Chiang, H. C., Hodson, A. C. 1972. Population fluctuations of the European corn borer, Ostrinia nubilalis, at Waseca, Minnesota, 1948-70. Environ. Entomol. 1:7-16

22. Chiang, H. C., Keaster, A. J., Read, G. L. 1968. Differences in ecological responses of three biotypes of Ostrinia nubilalis from the North Central United States. Ann. Entomol. Soc. Am. 61:140-46

23. Chiang, H. C., Kim, K. C., Brown, B. W. 1970. Morphometric variability related to ecological conditions of three biotypes of Ostrinia nubilalis in the North Central United States. Ann. Entomol. Soc. Am. 63:1013-16

24. Chiang, H. C.et al 1961. Populations of European corn borer, Ostrinia nubilalis (Hbn) in field corn, Zea mays (L.). Mo. Univ. Agr. Exp. Sta. Res. Bull. 776, 95 pp.

25. Chippendale, G. M. 1972. Composition of meridic diets for rearing plant-feeding lepidopterous larvae. Proc. $N$. Cent. Br. Entomol. Soc. Am. 27:114-21

26. Cornf ord, M. E., Rowley, W. A., Klun, J. A. 1973. Scanning electron microscopy of antennal sensilla of the European corn borer, Ostrinia nubilalis. Ann. Entomol. Soc. Am. 66:1079-88
27. Dicke, F. F. 1972. Philosophy on the biological control of insect pests. J. Environ. Qual. 1:249-53

28. Dicke, F. F., Jarvis, J. L. 1962. The habits and seasonal abundance of Orius insidiosus (Say) on corn. J. Kans. Entomol. Soc. 35:339-44

29. Drecktrah, H. G., Brindley, T. A. 1967. Morphology of the internal reproductive systems of the European corn borer. Iowa State J. Sci. 41:467-80

30. Drecktrah, H. G., Knight, K. L., Brindley, T. A. 1966. Morphological investigations of the internal anatomy of the fifth larval instar of the European corn borer. Iowa State J. Sci. 40:257-86

31. Durant, J. A. 1969. Seasonal history of the European corn borer at Florence, South Carolina. J. Econ. Entomol. 62:1072-75

32. Eden, W. G. 1959. Research on European corn borer in Alabama. J. Ga. Entomol. Soc. 5:1-3

33. Edwards, C. R., Berry, E. C. 1972. Evaluation of five systemic insecticides for control of the European corn borer. J. Econ. Entomol. 65:1129-32

34. Esterline, A. L., Zimmack, H. L. 1972. Histological effects of Escherichia coli and Serratia marcescens upon the European corn borer. J. Econ. Entomol. 65:283-84

35. Everett, T. R., Chiang, H. C., Hibbs, E. T. 1958. Some factors influencing populations of European corn borer, $P y$ rausta nubilalis (Hbn.) in the north central states. Minn. Univ. Agr. Exp. Sta. Tech. Bull. 229, 63 pp.

36. Franklin, R. T., Holdaway, F. G. 1966. A relationship of the plant to parasitism of European corn borer by the tachinid parasite Lydella grisescens. J. Econ. Entomol. 59:440-41

37. Frye, R. D. 1972. Evaluation of insect predation on European corn borer in North Dakota. Environ. Entomol. 1:535-36

38. Frye, R. D. 1972. Bird predation on the European corn borer. N. Dak. Farm Res. 29:28-30

39. Gallun, R. L., Starks, K. J., Guthrie, W. D. 1975. Plant resistance to insects attacking cereals. Ann. Rev. Entomol. 20:337-57

40. Guthrie, W. D. 1974. Techniques, accomplishments and future potential of breeding for resistance to European corn borer in corn. In Biological Control of Plants Insects and Diseases, ed. F. G. Maxwell, F. A. Harris, 359-80. Jackson, Miss.: Univ. Press. 670 pp. 
41. Guthrie, W. D., Dicke, F. F. 1972. Resistance of inbred lines of dent corn to leaf feeding by 1st-brood European corn borers. Iowa State J. Sci. 46:339-57

42. Guthrie, W. D., Carter, S. W. 1972. Backcrossing to increase survival of larvae of a laboratory culture of the European corn borer on field corn. Ann. Entomol. Soc. Am. 65:108-9

43. Guthrie, W. D., Dicke, F. F., Neiswander, C. R. 1960. Leaf and sheath feeding resistance to the European corn borer in eight inbred lines of dent corn. Ohio Agr. Exp. Sta. Res. Bull. 860, 38 pp.

44. Guthrie, W. D., Dicke, F. F., Pesho, G. R. 1965. Utilization of European corn borer egg masses for research programs. Proc. N. Cent. Br. Entomol. Soc. Am. 20:48-50

45. Guthrie, W. D., Dollinger E. J., Stetson, J. F. 1965. Chromosome studies of the European corn borer, smartweed borer, and lotus borer. Ann. Entomol. Soc. Am. 58:100-5

46. Guthrie, W. D., Huggans, J. L., Chatterji, S. M. 1969. Influence of corn pollen on the survival and development of 2nd-brood larvae of the European corn borer. Iowa State J. Sci. 44:185-92

47. Guthrie, W. D., Huggans, J. L., Chatterji, S. M. 1970. Sheath and collar feeding resistance to the second-brood $\mathrm{Eu}$ ropean corn borer in six inbred lines of dent corn. Iowa State J. Sci. 44:297-311

48. Guthrie, W. D., Russell, W. A., Jennings, C. W, 1971. Resistance of maize to second-brood European corn borers. Ann. Corn Sorghum Res. Conf. Proc. 26:165-79

49. Guthrie, W. D., Raun, E. S., Dicke, F. F., Pesho, G. R., Carter, S. W. 1965. Laboratory production of European corn borer egg masses. Iowa State J. Sci. 40:65-83

50. Harding, J. A. 1966. Field studies with crop protection chemicals against the European corn borer. USDA-ARS Special Rep. V-369. Ankeny, Iowa. $14 \mathrm{pp}$.

51. Harding, J. A. 1967. Chemosterilization of male European corn borers by feeding of tepa and apholate to larvae. J. Econ. Entomol. 60:1631-32

52. Harding, J. A., Dyar, R. C. 1970. Resistance induced in the European corn borer in the laboratory by exposing successive generations to DDT, diazinon, or carbaryl. J. Econ. Entomol. 63:250-53

53. Harding, J. A., Lovely, W. G., Dyar, R. C. 1968. Field tests of chemicals for control of the European corn borer. $J$. Econ. Entomol. 61:1427-30
54. Harding, J. A., Brindley, T. A., Corley, C., Lovely, W. G. 1971. Effect of corn row spacing and of plant populations on establishment and control of the European corn borer. J. Econ. Entomol. 64:1524-27

55. Harding, J. A., Corley, C., Beroza, M., Lovely, W. G. 1969. Residues of diazinon on field corn treated with granular, capsular, and ULV formulations for control of the European corn borer. $J$. Econ. Entomol. 62:832-33

56. Hayes, D. K., Reynolds, P. S., McGuire, J. U., Schechter, M. S. 1972. Synthesis of macromolecules in diapausing and nondiapausing larvae of the European corn borer. J. Econ. Entomol. 65:676-79

57. Hill, R. E., Keith, D. L. 1971. Corn borers-population fluctuation and control. Nebr. Farm Ranch Home Quart. 18:16-20

58. Hill, R. E., Chiang, H. C., Keaster, A. J., Showers, W. B., Reed, G. L. 1973. Seasonal abundance of the European corn borer, Ostrinia nubilalis (Hbn.), within the North Central States. Nebr. Agr. Exp. Sta. Res. Bull. 255, 82 pp.

59. ${ }^{\circ}$ Hill, R. E. et al 1967. European corn borer, Ostrinia nubilalis (Hbn.). Population in field corn, Zea mays (L.), in the North Central United States. Nebr. Agr. Exp. Sta. Res. Bull. 225, 100 pp.

60. Hills, T. M., Peters, D. C., Berry, E. C. 1972. Timing of insecticide applications to control the western rootworm and the European corn borer. J. Econ. Entomol. 65:1697-1700

61. Hofmaster, R. N., Waterfield, R. L., Boyd, J. C. 1967. Insecticides applied to the soil for control of eight species of insects on Irish potatoes in Virginia. $J$. Econ. Entomol. 60:1311-18

62. Hudon, M. 1963. Further field experiments on the use of Bacillus thuringiensis and chemical insecticides for the control of the European corn borer, Ostrinia nubilalis, on sweet corn in Southwestern Quebec. J. Econ. Entomol. 56:804-8

63. Hudon, M. 1965. First recovery of the imported parasite, Simpiesis viridula, (Thomson), of the European corn borer, Ostrinia nubilalis (Hübner), in Quebec. Phytoprotection 46:113-15

64. Huggans, J. L., Guthrie, W. D. 1970. Influence of egg source on the efficacy of European corn borer larvae. Iowa State J. Sci, 44:313-53

65. Jackson, R. D. 1963. Insecticide screening tests on European corn borer. Proc. N. Cent. Br. Entomol. Soc. Am. 18:73 
66. Jackson, R. D. 1965. Chemical control of the European corn borer in field tests in 1963. USDA-ARS Special Rep. V321. Ankeny, Iowa. $15 \mathrm{pp}$.

67. Jackson, R. D. 1965. Chemical control of the European corn borer in field tests in 1964. USDA-ARS Special Rep. V328. Ankeny, Iowa. 9 pp.

68. Jackson, R. D., Brindley, T. A. 1971. Hempa and metepa as chemosterilants of imagos of the European corn borer. J. Econ. Entomol. 64:1065-68

69. Jarvis, J. L., Brindley, T. A. 1965. Predicting moth flight and oviposition of European corn borer by the use of temperature accumulations. J. Econ. Entomol. 58:300-2

70. Jennings, C. W., Russell, W. A., Guthrie, W. D. 1974. Genetics of resistance in maize to first- and second-brood European corn borer. Crop Sci. 14:In press

71. Jennings, C. W., Russell, W. A., Guthrie, W. D., Grindeland, R. L. 1974. Genetics of resistance in maize to secondbrood European corn borer. Iowa State J. Res. 48:267-80

72. Jones, J. A. 1973. Postembryonic development of the reproductive system of the European corn borer, Ostrinia nubilalis (Hübner). $\mathrm{PhD}$ dissertation. Iowa State Univ., Ames, Iowa. 167 pp.

73. Kim, K., Chiang, H. C., Brown, B. W. 1967. Morphometric differences among four biotypes of Ostrinia nubilalis. Ann. Entomol. Soc. Am. 60:796-801

74. Klun, J. A. 1968. Isolation of a sex pheromone of European corn borer. $J$. Econ. Entomol. 61:484

75. Klun, J. A., Brindley, T. A. 1970. Cis-11-tetradecenyl acetate a sex stimulent of European corn borer. J. Econ. Entomol. 63:779-80

76. Klun, J. A., Robinson, J. F. 1971. European corn borer moth: Sex attractant and sex attraction inhibitors. Ann. Entomol. Soc. Am. 64:1083-86

77. Klun, J. A., Robinson, F. J. 1972. Olfactory discrimination in the European corn borer and several pheromonally analogous moths. Ann. Entomol. Soc. Am. 65:1337-40

78. Klun, J. A. et al 1973. Insect pheromones: Minor amount of opposite geometrical isomer critical to sex attraction. Science 181:661-63

79. Lewis, L. C., Lynch, R. E. 1969. Rearing the European corn borer, Ostrinia nubilalis (Hübner), on diets containing corn leaf and wheat germ. Iowa State J. Sci. 44:9-14

80. Lewis, L. C., Lynch, R. E. 1970. Treatment of Ostrinia nubilalis larvae with
Fumidil B to control infections caused by Perezia pyraustae. J. Invertebr. Pathol. 15:43-48

81. Lewis, L. C., Lynch, R. E., Berry, E. C. 1973. Synthetic juvenile hormones: Activity against the European corn borer in the field and the laboratory. J. Econ. Entomol. 66:1315-17

82. Loughner, G. E. 1971. Precopulatory behavior and mating success of the European corn borer under controlled conditions. Iowa State J. Sci. 46:1-5

83. Loughner, G. E. 1972. Mating behavior of the European corn borer, Ostrinia nubilalis, as influenced by photoperiod and thermoperiod. Ann. Entomol. Soc. Am. 65:1016-19

84. Loughner, G. E., Brindley, T. A. 1971. Mating success of the European corn borer, Ostrinia nubilalis, as influenced by environmental factors. Ann. Entomol. Soc. Am. 64:1091-94

85. Lynch, R. E., Brindley, T. A., Lewis, L. C. 1972. Influence of photophase and temperature on survival and oxygen consumption of diapausing European corn borers. Ann. Entomol. Soc. Am. 65:433-36

86. Matteson, J. W., Decker, G. C. 1964. Development of the European corn borer at controlled constant and variable temperatures. J. Econ. Entomol. 58:344-49

87. McWhorter, G. M., Berry, E. C., Lewis, L. C. 1972. Control of the European corn borer with two varieties of Bacillus thuringiensis. J. Econ. Entomol. 65: 1414-17

88. Miller, M. C. 1971. Parasitism of the corn earworm, Heliothis zea, and the European corn borer, Ostrinia nubilalis, on corn in North Georgia. J. Ga. Entomol. Soc. 6:246-49

89. Munson, R. E., Brindley, T. A., Peters, D. C., Lovely, W. G. 1970. Control of both the European corn borer and western rootworm with one application of insecticide. J. Econ. Entomol. 63: 385-90

90. Oloumi-Sadeghi, H. 1973. Development of methods for the prediction of European corn borer flight and egg deposition. PhD dissertation. Iowa State Univ, Ames. $237 \mathrm{pp}$.

91. Penny, L. H., Scott, G. E., Guthrie, W. D. 1967. Recurrent selection for European corn borer resistance in maize. Crop Sci. 7:407-9

92. Pesho, G. R., Dicke, F. F., Russell, W. A. 1965. Resistance of inbred lines of corn (Zea mays L.) to the second brood of the European corn borer, [Ostrinia 
nubilalis (Hübner)]. Iowa State J. Sci. 40:85-98

93. Raun, E. S. 1963. Corn borer control with Bacillus thuringiensis Berliner. Iowa State J. Sci. 38:141-50

94. Raun, E. S. 1963. A virus-like disease of the European corn borer. Proc. N. Cent. Br. Entomol. Soc. Am. 18:21

95. Raun, E. S., Jackson, R. D. 1966. Encapsulation as a technique for formulating microbial and chemical insecticide. J. Econ. Entomol. 59:620-22

96. Raun, E. S., Sutter, G. R., Revelo, M. A. 1966. Ecological factors affecting the pathogenicity of Bacillus thuringiensis var. thuringiensis to the European corn borer and fall armyworm. J. Invertebr. Pathol. 8:365-75

97. Raun, E. S., Lewis, L. C., Picken, J. C., Hotchkiss, D. K. 1967. Gamma irradiation of European corn borer larvae. $J$. Econ. Entomol. 60:1724-30

98. Reed, G. L., Showers, W. B., Huggans, J. L., Carter, S. W. 1972. Improved procedure for mass rearing the European corn borer. J. Econ. Entomol. 65: $1472-76$

99. Roelof s, W. L., Carde, R. T., Vartell, R. J., Tierney, P. G. 1972. Sex attraction trapping of the European corn borer in New York. Environ. Entomol. 1:606-8

100. Russell, W. A. 1972. A breeder looks at host plant resistance for insects. Proc. N. Cent. Br. Entomol. Soc. Am. 27:77-87

101. Ryder, J. C., Burbutis, P. P., Kelsey, L. P. 1969. Systemic insecticides for control of European corn borer and green peach aphid on peppers. J. Econ. Entomol. 62:1150-51

102. Scott, G. E., Dicke, F. F., Penny, L. H. 1966. Location of genes conditioning resistance in corn to leaf feeding of the European corn borer. Crop Sci. 6:444-46

103. Scott, G. E., Guthrie, W. D., Pesho, G. R. 1967. Effect of second-brood European corn borer inf estations on $\mathbf{4 5}$ single-cross corn hybrids. Crop Sci. 7:229-30

104. Scott, G. E., Hallauer, A. R., Dicke, F. F. 1964. Types of gene action conditioning resistance to European corn borer leaf feeding. Crop. Sci. 4:603-4

105. Showers, W. B., Reed, G. L. 1969. Effect of host population levels on incidence of parasitism by a Eulophid wasp. Proc. N. Cent. Br. Entomol. Soc. Am. 24:111-14

106. Showers, W. B., Reed, G. L. 1971. Three generations of European corn borer in central Iowa. Proc. N. Cent. Br. Entomol. Soc. Am. 26:53-56

107. Showers, W. B., Brindley, T. A., Reed, G. L. 1972. Survival and diapause characteristics of hybrids of three geographical races of the European corn borer. Ann. Entomol. Soc. Am. 65:450-57

108. Showers, W. B., Lewis, L. C., Reed, G. L. 1968. A possible marker for European corn borer moths. J. Econ. Entomol. 61:1464-65

109. Showers, W. B., Reed, G. L., Brindley, T. A. 1971. An adaptation of the Eu. ropean corn borer in the Gulf South. Ann. Entomol. Soc. Am. 64:1369-73

110. Showers, W. B., Reed, G. L., OloumiSadeghi, H. 1974. European corn borer: Attraction of males to synthetic lure and to females of different strains. Environ. Entomol. 3:51-58

111. Sisson, D. V., Brindley, T. A., Bancroft, T. A. 1965. Combining biological data from European corn borer experiments over years. Iowa State J. Sci. 39:403-5

112. Sparks, A. N. 1963. Preliminary studies of factors influencing mating of the European corn borer. Proc. N. Cent. Br. Entomol. Soc. Am. 18:95

113. Sparks, A. N. 1963. The use of inf ra-red photography to study mating of the European corn borer. Proc. N. Cent. Br. Entomol. Soc. Am. 18:96

114. Sparks, A. N. 1966. A microchamber for replicating photophases in diapause studies with the European corn borer. J. Econ. Entomol. 59:492-93

115. Sparks, A. N., Facto, L. A. 1966. Mechanics of inf rared cinematography in studies with the European corn borer. J. Econ. Entomol. 59:420-22

116. Sparks, A. N., Young, J. R. 1971. European corn borer activity in Georgia. J. Ga. Entomol. Soc. 6:211-15

117. Sparks, A. N., Brindley, T. A., Penny, N. D. 1966. Laboratory and field studies of $F_{1}$ progenies from reciprocal matings of biotypes of the European corn borer. J. Econ. Entomol. 59:915-21

118. Sparks, A. N., Raun, E. S., Carter, S. W. 1963. Lydella grisescens R. D. populations in corn borers of Boone County, Iowa. Proc. N. Cent. Br. Entomol. Soc. Am. 18:20-21

119. Sparks, A. N., Chiang, H. C., Burkhardt, C. C., Fairchild, M. L., Weekman, G. T. 1966. Evaluation of the influence of predation on corn borer populations. J. Econ. Entomol. 59:104-7

120. Sparks, A. N., Chiang, H. C., Keaster, A. J., Fairchild, M. L., Brindley, T. A. 1966. Field studies of European corn 
borer biotypes in the midwest. J. Econ. Entomol. 59:922-28

121. Sparks, A. N., Chiang, H. C., Triplehorn, C. A., Guthrie, W. D., Brindley, T. A. 1967. Some factors influencing populations of the European corn borer, Ostrinia nubilalis (Hubner), in the North Central States: Resistance of corn, time of planting, and weather conditions. Part II. N. Cent. Reg. Res. Publ. 180 (Iowa State Univ. Agr. Home Econ. Exp. Sta. Res. Bull.) 559:66-103

122. Sutter, G. R., Raun, E. S. 1967. Histopathology of European corn borer larvae treated with Bacillus thuringiensis. J. Invertebr. Pathol. 9:90-103
123. VanDenburg, R. S., Burbutis, P. P. 1962. The host-parasite relationship of the European corn borer, Ostrinia nubilalis, and the protozoan, Perezia pyraustae, in Delaware. J. Econ. Entomol. 55:65-67

124. Wall, M. L., Whitcomb, W. H. 1964. The effect of bird predators on winter survival of the southern and European corn borers in Arkansas. J. Kans. Entomol. Soc. 37:187-92

125. Wressel, H. B. 1973. The role of parasites in the control of the European corn borer, Ostrinia nubilalis, in Southwestern Ontario. Can. Entomol. 105:553-57 